\title{
Models of Analysis of the European Commission Leadership
}

\author{
Raluca Farcas, MA \\ Department of International Studies and Contemporary History, \\ Babes-Bolyai University, Romania
}

Doi:10.19044/esj.2020.v16n20p1 ～URL:http://dx.doi.org/10.19044/esj.2020.v16n20p1

\begin{abstract}
This paper aims to analyze the leadership models of the European Commission in terms of the function of setting the agenda of the European Union and in terms of political leadership. In this context, at the European level leadership is shared between several actors, making it difficult for the European Commission to exercise leadership traditionally, mostly for its lack of direct decision-making powers. Thus, the most relevant political roles of the President of the European Commission are to set the European agenda and to persuade and influence the other stake-holders to follow his directions for deepening European integration. In this regard, the article comparatively analyzes the leadership of Jacques Delors, Jean-Claude Juncker, and Ursula von der Leyen to identify the leadership model proposed at the beginning of their term, and to what extent, they exercised a political role. The tools used in the analysis are the inaugural speeches and the following three variables: how they organized the Commission to strengthen the political role of the President, how they mobilized resources from the other institutions of the European Union, and the formation of coalitions and networks. The article concluded that the leadership model proposed by Ursula von der Leyen falls within the supranational pattern of Delors' time, moving away from the model of political leadership proposed by Juncker. The accuracy of the research is limited by the fact that Ursula von der Leyen is only in her first year as President of the European Commission.
\end{abstract}

Keywords: European Commission, agenda-setting, political leadership, Ursula von der Leyen, Spitzenkandidaten, entrepreneurial leadership

\section{Introduction}

The leadership of the European Commission is difficult to identify, given the fragmented and polycentric structure of the European Union, where several actors share the leadership exercise, and unlike the governments of the 
Member States, which carry out their leadership activity in a relatively stable environment, the Commission Presidency exercises its leadership in an unpredictable context. Thus, the political leadership of the Commission, in the traditional sense, is less visible at European level, due to the lack of direct decision-making powers, the main way of exercising a political role and extensive use of powers is through agenda-setting. In other words, in their mission of deepening European integration (Nugent, 1995, p. 609), the President of the Commission does not hold the monopoly of leadership in the European Union, though they exercise leadership, a capacity that can be measured according to the institutional, situational and personal resources (Endo, 1999, pp.19-26) and the context in which it operates (Nugent, 1995, p. 605). Given that, like the European Commission, other actors play an important role in the negotiations on the future of the European Union, its role in shaping and influencing the agenda is not exclusive. However, throughout the history of European integration, the European Commission has played a central role in taking the initiative and introducing major changes at Union level. In this respect, the Commission's initiatives towards the Single European Market, the Single European Act, and the European Monetary Union should be recalled during Delors's presidency (Nugent, 1995, pp. 619-620).

Therefore, the most relevant role of the political leadership of the Presidents of the Commission, given their right of initiative in decisionmaking, is that of shaping and influencing the agenda through agenda-setting (Müller, 2017, p. 130). Firstly, the European Commission has the role of convincing and influencing the other actors of the European Union to follow its position, regarding the future of the Union, thus acting as a directional political leadership. Secondly, it plays an important role in the legislative initiative, acting as policy entrepreneurship and shaping the decision-making process, acting within the meaning of its adjudication (Nugent \& Rhinard, 2017, pp. 10-12). Thirdly, the Commission can act as a leader through treaty reform (Kassim \& Dimitrakopoulos, 2006, pp. 102-103). The Commission is noted in the activities of policy initiation, process facilitation, policy management and implementation (Nugent \& Rhinard, 2019, pp. 207-214), and like the Council is acting as agenda manager and broker in the negotiations (but see Tallberg, 2006, pp. 29-31, 2010, p. 243; Borrás, 2007, pp. 5-6; Gatti \& Manzini, 2012, p. 1714).

Furthermore, the leadership of the European Commission can be analyzed according to the resources it has and how it exploits them, the context of the negotiations in which it takes place, and the chosen strategy (Mazzucelli \& Beach, 2006, pp. 10-18). The European Commission can adopt a style of structural leadership (through the use of material resources to forge an area of possible agreement) or instrumental (through the managing agenda, the creation of compromises and coalitions, but also through brokerage) 
(Mazzucelli \& Beach, 2006, pp. 17-18). In addition, the Commission may also adopt a style of institutional, agenda-setting, mediation and public leadership (Endo, 1999, p. 28, 36; Müller, 2019, p. 3; Müller, 2016, p. 69; Tömmel, 2019, pp. 5-8). In the studies conducted on the leadership of the European Commission, a series of classifications of its leaders can be found, according to the activity undertaken: active presidential, steered presidential, primus inter pares, passive chair (Kassim, 2013, pp. 9-11), symbolic, adaptative (Maythorne \& Peterson, 2010, pp. 14-15), structural, instrumental (Mazzucelli \& Beach, 2006, pp. 10-18; Hodson, 2013), agenda-setters, popularisers, inventors, brokers (Young, 1991, pp. 284-286).

Current research offers a wide range of studies conducted from the perspective of the resource structure and constraints of the European Commission, considering that Jacques Delors managed them to the highest degree, using them extensively and acting to minimize constraints (Endo, 1999; Blondel, 1987; Nugent, 1995; Tömmel, 2013, 2018, 2019; Müller, 2020, 2016; Bürgin, 2017; Kassim, 2013, 2019a; Ross \& Jenson, 2017). In his work, the President of the European Commission exercises his leadership both in the supranational framework of the Commission and in the intergovernmental environment of the European Council, which is one of its most important resources, in order to shape and influence the agenda (Endo, 1999, pp. 54-55). The leadership performance of the European Commission can be measured by three dynamics: static (the function holder acts only within the resource and constraint structure); mobilization (acts by exploiting resources and constraints, reducing constraints); structural change (acts to expand and create new resources and opportunities, minimizing constraints) (Endo, 1999, p. 27). The Commission's leadership has a crucial role in the negotiation process regarding the new reform initiatives of the European Union, which are introduced on the European agenda, and in this respect, there are several stages in the negotiation process of the European Commission, as they were identified in leadership literature: firstly, the diagnosis phase, secondly, the formula phase and thirdly, the agreement phase (Mazzucelli \& Beach, 2006, p. 18), which can be associated with three functions of the Commission, namely agenda-setting leadership (for the first phase), mediative leadership (for the second phase) and brokerage leadership (for the third phase). This analogy can be explained by the fact that in the diagnosis phase the premises of a solution creation appear, in the formula phase solutions are created and inter-institutional coalitions are formed, and in the agreement phase brokerage is made for joint gains (Mazzucelli \& Beach, 2006, p. 18).

Regarding the agenda-setting function, it is ideal that it be carried out under monopoly conditions over the initiative and independence from ad hoc pressure. Additionally, in the context of agenda-setting, formal governance can be referred to when the Commission "selectively bars some governmental 
initiatives from the legislative agenda" or informal governance when the Commission "customarily endorses governmental proposals" (Kleine, 2013, pp. 43-48). It is considered that the level of ambition, the style, the resources mobilized are determining factors in the impact of the Commission leader on the shaping and setting of the agenda (Kassim, 2013, p. 9; Endo, 1999, p. 26). It is well-known that the agenda-setting leadership has become visible since the beginning of the European Commission, with the Customs Union acceleration program (initiated by Hallstein), the re-launch of the Monetary Union initiative through the European Monetary System (by Jenkins), the shaping of the ESPRIT initiative (by Thorn), initiatives on the Single European Market, negotiations on the Single European Act, the launch of the European Monetary Union plan and the White Paper on the Internal Market (owned by Delors) (Endo, 1999, pp. 38-39; Hodson, 2016).

That being said, the agenda-setting is relevant in the new context of the Presidency of Ursula von der Leyen, who has ambitiously outlined her agenda, wishing to advance in directions that the previous Commission was not successful, establishing as the main directions of action the deepening The Monetary Economic Union, the reform Dublin regulations on migration and asylum ("New Pact on Migration and Asylum"), the full implementation of the European Pillar of Social Rights. However, the most important ambition of the new President of the Commission is "The European Green Deal", a program that aims to transform Europe into the first continent with a neutral climate, by 2050 , at the same time, stimulating the competitiveness, innovation, competition of European industry, and also a plan to reduce European Union emissions by 2030 (Von der Leyen, 2019a). Thus, by achieving the objectives of this plan, a circular economy would be created, which promotes the sustainable use of resources. It is quite clear that Ursula von der Leyen has acted to set the European Union's agenda, by pursuing ambitious goals and therefore, in the context of setting the European agenda from the zero point, an association can be seen between Leyen's ambitious directions with those of Delors in 1985 when he exercised agenda-setting leadership by launching the Single European Market program. On the other hand, Juncker attempted to create a political commission, as a form of strengthening the position of President of the Commission, as he had stated before the European Parliament in July 2014, being the first President elected through the Spitzenkandidaten process (Kassim \& Laffan, 2019b, p. 51). In this context, several studies have conducted the analysis over Juncker's political leadership, following the introduction of the Spitzenkandidaten model, focusing on how he managed to mobilize resources for influencing and shaping the agenda (but see Kassim \& Laffan, 2019; Kassim et.al., 2019a; Tömmel, 2018, 2019; Müller, 2013, 2020; Bürgin, 2017; Peterson, 2016; Darmé, 2019; Hanck, 2018). Therefore, it is interesting to note the extent to 
which Leyen is closer to Juncker's model of the political commission or Delors's supranational model.

\section{Research question and methodology}

The research problem of this article focuses on identifying the leadership model proposed by Jacques Delors, Jean-Claude Juncker, and Ursula von der Leyen at the beginning of the term and to what extent they exercised a political role. This article seeks to answer the following research question: To what extent has Ursula von der Leyen's leadership moved away from Juncker's model of political leadership and reverted to the supranational pattern of Delors' time?

Therefore, this article analyzes the leadership models of the European Commission through its agenda-setting role, following the capacities and abilities in shaping and influencing the Community decision-making process. In this regard, the article makes a comparative analysis of the leadership of Delors, Juncker and von der Leyen, which attempts to identify the leadership model proposed by each at the beginning of their term. As such, the relevant analysis tools for establishing the leadership style adopted in agenda-setting are the candidacy and inaugural speeches, and the method applied to the selected instruments (the speeches) is the comparison of the discourse analysis. Hence, the analysis of the inaugural speeches will use the relevant theoretical framework to identify the appropriate types of leadership for setting the agenda, following Young's (1989, 1991) typology: structural, entrepreneurial and intellectual. The discourse analysis will take into consideration the descriptors and concepts derived from Young's taxonomy of leadership styles, in order to see which of these descriptors are predominant for the three leaders.

On the other hand, regarding to the capacity of shaping and influencing the decision-making process (in other words, the political leadership of the European Commission), the analysis will use the following variables, considered to be determining factors for the success of the Commission: firstly, the Commission design will be analyzed, in order to establish whether it is organised in that manner for a political Commission or for the purpose of strengthening the political power of the President (the political nature of the organizational charts of the three Colleges of Commissioners will be analyzed here); secondly, the article will take into consideration how Delors, Juncker and Leyen mobilized resources from the main institutions of the European Union (their relationship with the European Parliament, the European Council and the Council); thirdly, the analysis will take into account the networks and coalitions created by Delors, Juncker and Leyen at the European Union level, which can determine the efficiency of the agenda-setting, whether it is about 
the relations with the Secretary-General, the chief of the presidential cabinet or the Franco-German tandem.

\section{Leadership style in setting the agenda}

Regarding the political leadership of the European Commission, there are two relevant approaches in this respect. On the one hand, the political leadership understood from agenda-setting point of view, by influencing and shaping the agenda, where the manner and extent to which the resources of the Commission were mobilized by the President is relevant (Müller, 2017: 130). On the other hand, the political leadership of the Commission can be understood, after 2014, from the perspective of the Spitzenkandidaten process, as can be found in Article 17 (7) of the Treaty on European Union: "Taking into account the elections to the European Parliament and after having held the appropriate consultations, the European Council, acting by a qualified majority, shall propose to the European Parliament a candidate for President of the Commission. This candidate shall be elected by the European Parliament by a majority of its component members. If he does not obtain the required majority, the European Council, acting by a qualified majority, shall within one month propose a new candidate who shall be elected by the European Parliament following the same procedure", when Juncker was the first president elected following this process. In this context, the Spitzenkandidaten process represents an attempt to address the democratic deficit of the European Union, through parliamentarization (Kassim \& Laffan, 2019b, p. 50). Even President Juncker stated before the European Parliament on the $15^{\text {th }}$ of July 2014 that: "The Commission is political. And I want it to be more political. Indeed, it will be highly political" (Juncker, 2014b, p. 1). Nevertheless, the first part of the research will follow Müller's approach to political leadership, namely from the perspective of the President's role in setting the agenda of the European Union.

On that account, in identifying the leadership style adopted by Delors, Juncker and von der Leyen when setting the European Union agenda, the paper will analyze their candidacy and inaugural speeches. In this sense, the discourse analysis will consider the descriptors and concepts from Young's taxonomy of leadership styles, namely structural, entrepreneurial, and intellectual (1991, pp. 287-288). Firstly, structural leadership is characterized by transforming material resources (structural powers) into negotiating leverage to reach an agreement (Young, 1991, p. 288; Mazzucelli \& Beach, 2006, pp. 17-18). The structural leadership uses two types of tactics to reach the desired agreement, for instance: a threat to stall the negotiation process, if concessions are not made in favour of its provisions and rewards to the parties that have followed its direction (Young, 1991, p. 289). Here, it is important to note that structural leadership is difficult to identify at the Commission level, 
due to its lack of structural power, but there are several situations where the President of the Commission used its prestige and the power of initiative in order to create leverage to attract more support from other institutions. Secondly, entrepreneurial leadership is defined as the negotiation skills used to influence the way issues are presented in the negotiations, modeling mutually acceptable agreements for all parties (Young, 1991, p. 288). It is worth mentioning that the entrepreneurial leaders fulfill several functions, as follows: agenda-setters (shaping the way issues are presented internationally), popularisers (draw attention to the important issues in the discussion), inventors (propose policies to overcome obstacles), brokers (striking deals) (Young, 1991, p. 294). Thirdly, intellectual leadership refers to the activity whereby a system of ideas is produced to model how negotiation participants understand the issues in question and the options available (Young 1991, pp. 298-301). Therefore, the analysis will take into account these concepts mentioned above. The following table illustrates more clearly the concepts considered in discourse analysis.

Table 1. Leadership style in institutional bargaining

\begin{tabular}{|c|c|c|c|}
\hline $\begin{array}{l}\text { LEADERSHIP } \\
\text { STYLE }\end{array}$ & STRUCTURAL & ENTREPRENEURIAL & INTELLECTUAL \\
\hline \multirow[t]{4}{*}{ DESCRIPTORS } & \multirow[t]{4}{*}{$\begin{array}{l}\text { - "the ability to } \\
\text { translate structural } \\
\text { power into } \\
\text { bargaining leverage } \\
\text { as a means of } \\
\text { reaching agreement } \\
\text { on the terms of } \\
\text { constitutional } \\
\text { contracts in social } \\
\text { settings of the sort } \\
\text { exemplified by } \\
\text { international } \\
\text { society". }\end{array}$} & $\begin{array}{l}\text { - "influence the manner } \\
\text { in which issues are } \\
\text { presented and to fashion } \\
\text { mutually acceptable } \\
\text { deals bringing willing } \\
\text { parties together on the } \\
\text { terms of constitutional } \\
\text { contracts yielding } \\
\text { benefits for all". } \\
\text { - "an agenda-setter and } \\
\text { populariser who uses } \\
\text { negotiating skill to } \\
\text { devise attractive } \\
\text { formulas and to broker } \\
\text { interests". }\end{array}$ & \multirow[t]{4}{*}{$\begin{array}{l}\text { - "intellectual capital } \\
\text { or generative systems } \\
\text { of thought that shape } \\
\text { the perspectives of } \\
\text { those who participate } \\
\text { in institutional } \\
\text { bargaining". } \\
\text { - "a thinker who } \\
\text { seeks to articulate the } \\
\text { systems of thought" } \\
\text { - "new visions and } \\
\text { the concerns they } \\
\text { engender are likely to } \\
\text { loom larger and } \\
\text { larger in institutional } \\
\text { bargaining processes } \\
\text { at the international } \\
\text { level". }\end{array}$} \\
\hline & & agenda-setters & \\
\hline & & popularisers & \\
\hline & & $\begin{array}{l}\text { inventors } \\
\text { brokers }\end{array}$ & \\
\hline
\end{tabular}

(Young 1991, pp. 287-300)

\section{Jacques Delors}

The literature offers many models of analysis on Jacques Delors' leadership. First of all, Delors is a good example of transformative leadership (Ross \& Jenson, 2017, p. 115, 124; Tömmel, 2013, p. 798), both in the management of the supranational commission and in its work within the intergovernmental European Council, for his power of conviction and 
persuasion on the importance of his initiatives. Delors' leadership is recognized as predominantly entrepreneurial, due to his success in creating the European Single Market, which has brought numerous possibilities for joint gains at the intergovernmental level (Ross \& Jenson, 2017, p. 118). Along the same line, Delors is a practitioner of mediative and agenda-setting leadership, noting in this regard, by the way he created and strengthened alliances (especially through the networks formed at the Commission level, led by the chief to his cabinet, Pascal Lamy, but also through his favorable connection with the Franco-German tandem represented by Mitterrand and Kohl), through striking deals that support his desired position, but also through initiatives such as Single European Act, European Monetary Union, White Paper (Endo, 1999, pp. 38-39). In other words, Delors has successfully exercised its leadership in setting the agenda, as this success in setting the agenda is not just about introducing innovative ideas or bringing new issues to the agenda, but about establishing coherent themes and strategies in the integrationist spirit (Müller, 2017, p. 140).

At the time of setting the European agenda, Delors acted as an entrepreneurial and intellectual leader. Delors was an entrepreneurial and intellectual leader since he shaped and influenced the agenda to reap joint gains for all the participants in the bargaining and he presented a new and innovative vision that was needed after a long stagnation phase in the European negotiations. Thus, in order to demonstrate this assertion, the article will analyze his speech from 14-15 January 1985 and establish which of Young's taxonomy concepts are more prominent.

To begin with, the article will analyze the elements of entrepreneurial leadership identified in Delors' speech, paying more attention to the four functions of the entrepreneurial leader, namely: agenda-setter, popularisers, inventors, brokers. First of all, Delors (1985, p. 5) changes the paradigm in which the problems faced by the European Community are presented and addressed by focusing on "how to go about it", and not on "what has to be done", as noted in his speech: I believe that the engineers of European integration are fumbling not over 'what has to be done' but rather over 'how to go about it'; What approach do I have in mind since my theme is, and will continue to be, 'how to go about it?'. Here, he acts as an agenda-setter, shaping the way issues are presented. Also, by the following sentence: it may not be over-optimistic to announce a decision to eliminate all frontiers within Europe by 1992 and to implement it, Delors (1985, p. 6) anticipates the creation of the Single European Market, which is the main purpose of the entrepreneurial leader, namely to influence how problems are presented in order to reap joint gains. More precisely, the S.E.M. allowed the creation of a win-win situation for all Member States, much needed in the context of collective action problems that the European Community was facing at the time. On the other 
hand, Delors (1985, p. 7) again acts as an agenda-setter and populariser for the main community issues, arguing that removing borders will not be enough to solve the problems regarding the high level of unemployment of Europeans. Further, Delors (1985, p. 9) assumes one more time the role of broker and populariser in his speech, drawing attention to the need to reach an agreement in collective bargaining, as follows: when will we see the first European collective bargaining agreement? [...] A European collective agreement is not just an empty slogan. It would provide a dynamic framework, one that respected differing views-a spur to initiative, not a source of paralysing uniformity. However, his role as a broker is even better highlighted in his actions of managing difficulties at the institutional level, as can be seen in: Should a difficulty arise between two institutions, the Commission will endeavour to decide whether the root cause is a fundamental difference of opinion between the Member States, or whether it is, quite simply, a confrontation between the powers of the institutions. [...] In the first case, where a fundamental difference of opinion is involved, it will be for the Council to initiate frank discussions and for Parliament to debate the issue and involve public opinion. In the second case, where a confrontation of powers or susceptibilities is involved, the Commission will attempt to act as honest broker to ensure that non-essentials-institutional friction-do not cloud essentials - the progress of European integration (Delors, 1985, p. 15).

As an agenda-setter, Delors (1985, pp. 9-10) establishes the three main directions of the Commission for the next four years, namely: a large market and industrial cooperation; the strengthening of the European Monetary System; and the convergence of economies to lead to higher growth and more jobs, drawing attention to the essential need for unity and integration, because what the European Community lacked was: [...] the benefit of scale and the multiplier effect; [...] a united team; [...] a single economic and social area. In this regard, Delors (1985, p. 18) emphasizes the importance of reaching agreements in negotiations, proposing a transition from the old type of diplomacy with a tit-for-tat approach to a unitary approach on diagnosis and strategic proposals, which can bring joint gains for all parties. Delors argues that the only time the European Community managed to convince the United States of America was when they had a unitary vision and position, thus being the reason why institutional quarrels that lead to stagnation must be avoided.

Here, Delors' role as an agenda-setter can be seen, as well as a broker, in trying to overcome the impediments in the negotiations, caused by the lack of unitary action, the institutional problems, the wide range of different opinions, the opposing positions, the divergent proposals and strategies, thus promoting unity at the level of the European Community. Additionally, Delors (1985, pp. 19-20) is a populariser, drawing attention to the lack of unity in the commercial market, as he argues: There is no point in wanting a strong ECU 
in a splintered market. Feudalism is just as out of place in monetary affairs as it is in economics and trade. Entrepreneurial leadership, according to Young, is an action by which an agreement is reached in order to reap acceptable gains for all parties (Young, 1991, p. 288), thus a win-win situation. This definition describes precisely what Delors (1985, p. 21) proposes to the European Parliament in the following excerpts: Why don't you, with the approval of your enlarged Bureau, let's say twice a year, choose a subject which you, rather than the Commission, would begin to study. Why don't you conduct the necessary hearings [...] and prepare a resolution as a basis for us to work on. I think that if we could get an arrangement of this kind going, there would be better understanding, more scope for cooperation between our two institutions. We wouldn't be climbing alone [...].

On the other hand, in terms of intellectual leadership, the analysis looks at those parts of the discourse that reveal Delors' ability to use the power of ideas in shaping intellectual capital. In this regard, the most important attempt to shape thinking is the call for a future European Union (Let us do what we can to ensure that by June, the deadline set by the European Council for a debate of the utmost importance, progress made towards strengthening our Community will justify our determination to press onwards to European Union) (Delors, 1985, p. 16). Moreover, Delors has proposed a new perspective on approach and understanding of the issues, acting to orient the parties on the available options. First, he has introduced a set of ideas about the main challenges, namely approach, in which he stands for unity; influence, through an active role of the Commission and civilization, by capitalizing on differences and diversity in a new construction (Delors, 1985, p. 16). Secondly, in his attempt to convince and influence the parties on the advantages of creating a Single European Market, Delors (1985, p. 11) argues that the burden of the national aid could be replaced, through cooperation at a larger scale between European firms, with financial incentives.

Thirdly, Delors (1985, p. 21) is trying to shape the thinking to act based on the current Treaty, rather than making a new one, highlighting the possible problems that could arise if hypothetically the 10 member states would agree to a new treaty, namely: When would this new treaty come into force? Three years later at the earliest. So what do we do for those three years? Do we meet to polish up the draft? To improve it? Or do we do nothing at all? [...] There is no need to abandon 'the great beyond' but we must go on working here and now within the existing Treaty, all of the Treaty.

That being said, Delors acted in the manner of an entrepreneurial leader for many reasons, as follows: first, in his speech, he influenced how the community problems are presented and established the future directions of action on the European agenda, being a populariser of the unitary and cohesive action; secondly, through brokerage he tried to manage the difficulties at the 
institutional level, emphasized the importance of reaching an agreement in negotiations and acted to overcome the impediments of the intra-institutional and inter-institutional negotiations caused by the problems of collective action; thirdly, Delors has acted to create win-win situations at the intergovernmental level, thus trying to obtain mutually acceptable agreements and common gains for all parties. On the other hand, Delors is also an intellectual leader, as he used the power of ideas to shape intellectual capital, identifying new ways of transposing problems, different from the old ideas, settled in the participants' minds. In other words, the most important ideas Delors used during his speech is the one that invokes the creation of the Single European Market and the European Union. And with these ideas, he is also an inventor, in the sense given by Young, because these initiatives came after a long period of stagnation in European affairs.

\section{Jean Claude Juncker}

Juncker's leadership is highly debated in the literature, especially for the particular character of the Spitzenkandidaten process. In this regard, the analysis conducted on Juncker's leadership takes into account the three dimensions identified by Endo (1999, p. 26), namely the institutional, situational and personal ones (but see Tömmel, 2018, 2019; Müller, 2019; Bürgin, 2017). Thus, in terms of his personal qualities, the following are relevant: his ability to bring new visions, policies and strategies for deepening European integration; its ability to convince other decision-makers to follow its directions and visions, through compromised brokering and negotiation skills (Tömmel, 2018, p. 139). In addition, Juncker's leadership model is important as it strengthened the Commission Presidency and continued in the direction of the Barosso Commission to strengthen cooperation relations with the European Parliament, thus operationalizing a political Commission through a series of structural and procedural reforms (Kassim \& Laffan, 2019b, pp. 53-54; Kassim et.al., 2019a, pp. 13-15).

When setting the agenda, Juncker acted in the manner of an entrepreneurial and structural leader. In this regard he acted in order to influence the way issues were presented before de members of the Parliament and he used the bargaining leverage for gaining more support for his desired directions. This statement will be demonstrated by analyzing his speech on 15 July 2014 before the European Parliament.

The first example for Juncker's (2014b, p. 2) entrepreneurial leadership can be seen in the change of approach regarding the issues at stake, from an intergovernmental approach to a team approach, which he calls the "Community method" (In Europe we should play as a team. Let us apply the Community method. Yes, it is demanding, but it is effective, it is tried and tested and it is more credible than intergovernmental wrangling. We need to 
restore the Community method). Juncker (2014a, p. 4) acts as an agenda-setter from the outset, arguing that the Commission will focus only on 10 policy areas, leaving Member States to address other issues, as he stated in the Political Guidelines for the next Commission: I want a European Union that is bigger and more ambitious on big things, and smaller and more modest on small things. In this regard, Juncker $(2014 \mathrm{~b}, \mathrm{p}$. 4) shapes how the problems of the agenda are presented, arguing that the European Union should not be solving all the problems of Europe, but only the major problems, as seen in the following excerpt: [...] the European Commission - and the European Union - concerns itself with the really major European issues instead of interfering from all angles in every detail of people's lives. Not every problem that exists in Europe is a problem for the European Union. We must take care of the big issues.

From his speech, it is clear that Juncker $(2014 b$, p. 2) will act in a reform direction, trying to get out of the resource and constraints structure that Endo was referring to, setting ambitious goals to make Europe more competitive (Europe needs a broad-based agenda for reform. [...] The status quo does not provide us with a full range of tools. It has to be extended). In addition, Juncker (2014b, pp. 3-5) becomes a populariser, but at the same time a broker by drawing the attention to the importance of the issues at stake and strikes deals for their solution, such as: competition (Competitiveness is essential to make the European Union a more attractive location. A location for people, for investors), renewable energies (Renewable energies and their development is a sine qua non if tomorrow's Europe really is going to create lasting, consistent and sustainable locational advantages), the refugee crisis (Illegal immigration and the refugee crisis are not the problems of Malta, Cyprus, Italy or Greece, they are the problems of Europe as a whole), unemployment (What we need is an ambitious package for employment, growth, investment and competitiveness. [...] If Europe invests more, Europe will be more prosperous and create more jobs), the completion of the internal market (The internal market has to be completed. If we are successful in this, we will add another $€ 200$ billion of added value to the European economy), the energy policy (We have to reorganise Europe's energy policy into a new European Energy Union. [...] We need to diversify our energy sources and reduce the high energy dependency of several of our member states), single digital market (Roaming charges in Europe have to disappear and they will disappear. If we are successful in implementing a real digital single market, we can generate $€ 250$ billion of additional growth in Europe). It is worth mentioning that Juncker $(2014 \mathrm{~b}, \mathrm{p}$. 3) is trying to shape the agenda in the direction of a social-economic market, emphasizing the importance of people and of the fact that the economy must serve the people and thus, the social dialogue should receive more attention. (The social market economy can only 
work if there is social dialogue. [...] I would like to be a President of social dialogue).

Moreover, Juncker (2014b, p. 5) set the agenda for Europe to become number one in renewable energy, just as Ursula von der Leyen has established that Europe will be the first climate-neutral continent (I want the European Union to become the world number one in renewables. We will contribute significantly to enhancing energy efficiency beyond the 2020 objective [...] A binding $30 \%$ objective for energy efficiency by 2030 is to me the minimum). On the other hand, Juncker also exercises the role of inventor, because he acts in order to eliminate obstacles that slow down the agreement and the unitary achievement of the objectives of the community institutions. In this regard, the following excerpt from his speech is relevant because, here, Juncker (2014b, p. 6) draws attention to the importance of unity, both in terms of Economic and Monetary Union, and the Common Foreign and Security Policy: I want the Economic and Monetary Union, and the euro, to be represented by a single chair and a single voice in the Bretton Woods institutions. [...] It would be fine by me if the High Representative of the Union for Foreign Affairs and Security Policy were no longer thwarted by the Foreign Ministers of the Member States and I will ensure this does not happen. A common foreign policy also needs a common external image.

Regarding intellectual leadership, although it cannot be said that Juncker has generated a system or capital of innovative ideas, practically continuing in the direction of the efforts made by the other Commissions, still his agenda has ambitious goals. Given the fact that Juncker began his term as President of the Commission in a context marked by a multitude of crises, such as the refugee crisis, the eurozone crisis and the possibility of a Grexit, the Ukrainian energy crisis and others, it was expected that the agenda would rise to the level of the international situation. Even though Juncker did not provide innovative intellectual capital, he supported the use of ideas that already exist (We cannot spend money we do not have. We have to replace deficits and debts by ideas. The ideas are there: we must make better use of the opportunities [...]), precisely like an entrepreneurial leader, as Young (1991, pp. 300-301) also acknowledges: "entrepreneurial leaders often become consumers of ideas generated by intellectual leaders". However, Juncker, as the first President elected through the Spitzenkandidaten process, comes with a new vision of the European Commission, namely a political commission. This is visible in the following paragraph: The Commission is political. And I want it to be more political. Indeed, it will be highly political. Its make-up must reflect the plurality of the majority of ideas which take shape, but also in operationalizing the structure of the Commission, as will be seen later in the article (Juncker, 2014b, p. 1). 
In Juncker's case, the analysis takes into consideration a possible structural leadership, because at one point in his speech he puts on his agenda the need to reform the Troika, noting that the European Parliament was the one who drew attention to the lack of its democratic character. Given these, the following fragment could be considered as a possible element of structural leadership: I would like us to reconsider the instrument of the Troika. The European Parliament has stated in reports on the subject that the Troika as it works at present lacks democratic substance. It does lack democratic substance; it lacks a parliamentary dimension. We must review the Troika and make it more democratic, more parliamentary and more political. We will do this (Juncker, 2014b, pp. 4-5). One possible reasoning is that Juncker, on the model of the bargaining leverage, has tried to attract even more support from Parliament by popularizing the Troika problem. Moreover, Juncker dedicated the entire beginning of his political guidelines to praise the Parliament for the Spitzenkandidaten system.

Therefore, Juncker's leadership is entrepreneurial and structural, because, it has shaped the agenda for the European Union to act big on big and small on small. Juncker also acted as a broker, making deals for the main issues at stake, such as the refugee crisis, renewable energy, unemployment, the single digital market and the social-economic market. Moreover, Juncker set the agenda by setting an ambitious target such as Europe being the first in renewable energy. On the other hand, Juncker is an inventor in that he introduces a new vision of the European Commission, namely a political commission, not a technocratic one. Furthermore, elements of structural leadership can be identified in Juncker's leadership, as they act as bargaining leverage to try to attract support from Parliament, as it refers to the need to reform the Troika and to the fact that it is the first Parliament that truly elected, given the Spitzenkandidaten procedure, which further strengthened the Commission's relationship with Parliament.

\section{Ursula von der Leyen}

Ursula von der Leyen adopted an entrepreneurial and intellectual leadership style when setting the agenda. In this regard, von der Leyen acted as an agenda-setter and broker by introducing environmental issues on the European agenda on the one hand and shaped the thinking by introducing a new vision, Green Deal, on the other. Therefore, in order to identify the leadership style approached by Ursula von der Leyen at the time of setting the agenda, the article will analyze her speeches from July 16 and November 27 , 2019.

To begin with, the ambitious character of the program proposed by von der Leyen can be seen from the title: A Union that strives for more. In terms of entrepreneurial leadership, von der Leyen (2019b, p. 2) assumes the role of 
agenda-setter, by setting the following goals on climate issues: I want Europe to become the first climate-neutral continent in the world by 2050. [...] Our current goal of reducing our emissions by $40 \%$ by 2030 is not enough. We must go further. We must strive for more. [...] I will put forward a Green Deal for Europe in my first 100 days in office. I will put forward the first ever European Climate Law which will set the 2050 target into law and the role of populariser (Von der Leyen, 2019c, p. 7) in order to draw attention to environmental issues that require urgent leadership and action.

Given the context of the international crises, with the taking over of the President's mandate, Ursula von der Leyen inherited a number of problems from the former Commission, for which she proposed a series of solution options, thus assuming the role of a broker. In other words, von der Leyen (2019b, p. 4) addressed issues that were not resolved by the Juncker Commission, such as: the refugee crisis, here emphasizing on unitary action and cooperation through the reformation of the Dublin regulations and a New Pact on Migration and Asylum (We must reduce irregular migration, we must fight smugglers and traffickers - it is organised crime -, we must preserve the right to asylum and improve the situation of refugees [...] A Common European Asylum System must be exactly that - common), United Kingdom withdrawal, which von der Leyen states that will remain an ally, unemployment, for which Ursula von der Leyen provided A European Unemployment Benefit Reinsurance Scheme, the completion of Capital Markets Union, through medium-sized enterprises ([...] the small and medium-sized enterprises. They are innovative, they are entrepreneurial, they are flexible and agile, they create jobs, they provide vocational training to our youth. But they can only do all this if they have access to capital everywhere in this huge Single market. Let's get rid of all the barriers. Let's open the door. Let's finally complete the Capital Markets Union) and a more united Europe ([...] we must have the courage to take foreign policy decisions by qualified majority). Moreover, von der Leyen (2019c, p. 13) shapes the agenda in such a way as to bring to the fore the two main objectives, which could underlie the change and which she names "the twin transition", as observed in her speech: The twin transition - climate and digitalisation - will bring changes for all [...]We should harness this transformative power of the twin climate and digital transition to strengthen our own industrial base and innovation potential. Further, von der Leyen $(2019 b$, p. 7) demonstrates through her speech that she has approached an entrepreneurial leadership style, which is most visible when she recognizes that she is assuming a mediator or broker role, because she has listened to the problems and has established the directions that can bring joint gains for both the Commission and the European Parliament as follows: [...] I want us to work together to improve the Spitzenkandidaten system. We need to make it more visible to the wider 
electorate and we need to address the issue of transnational lists at the European elections as a complementary tool of European democracy. [...] I support a right of initiative for the European Parliament. When this House, acting by majority of its Members, adopts Resolutions requesting the Commission to submit legislative proposals, I commit to responding with a legislative act in full respect of the proportionality, subsidiarity, and better law-making principles. It is possible that she acted in the same way Juncker did, by trying to attract more support from the Parliament, by using the negotiation leverage strategy and thus being a structural leader.

In terms of intellectual leadership, as in Delors' case, Leyen set the agenda from ground zero, proposing a new approach to existing issues, a system of ideas that would shape thinking. In other words, if in Delors' case there is the Single European Market and the European Union, in the case of Leyen there is Green Deal. On the other hand, if Juncker created a political Commission, as the first President elected through Spitzenkandidaten, von der Leyen (2019b, p. 6) created a Commission based on gender equality, as the first female president. These actions can be considered as elements of an innovative, modernization and reform vision (As the first woman to be president of the Commission, every Member of my College will have a genderbalanced Cabinet -for the very first time. And by the end of our mandate, we will have gender equality at all levels of management-for the very first time).

To sum up, Ursula von der Leyen is a practitioner of entrepreneurial leadership because she has shaped and set the agenda for climate issues, acting as a populariser for the urgent need to make Europe the first climate-neutral continent. Also, given the fact that she inherited several unsolved issues from the Juncker Commission, von der Leyen acted as a broker, providing solutions and presenting the options available for these issues (migration, Brexit, unemployment). Moreover, she acted as an inventor, proposing a new problem management strategy, namely through twin transition-climate and digitalization. Finally, von der Leyen is also an intellectual leader, as she shaped the thinking by introducing a new approach to the issues at hand, namely the Green Deal.

\section{The political leadership of the European Commission}

Having an image of their leadership styles, this chapter will focus on how the three Commission presidents have exercised their political leadership by influencing and shaping the decision-making process. In this respect, the following variables will be considered: first, what is the proposed Commission design (the College of Commissioners' organizational chart); secondly, the way they mobilized resources from the main European institutions; third, how they formed networks and coalitions, both intra-institutionally and interinstitutionally. 


\section{Jacques Delors}

Delors has exercised his political leadership mainly through the relations with the Franco-German tandem and the ad hoc networks formed at the level of the European Commission, these being his most important resources. However, to demonstrate this, the three variables mentioned above will be considered.

First, regarding the political design of Delors's team, it consists of: 2 former Deputy Prime Ministers, 9 former Ministers, 4 returning Commissioners and 3 former Members of the European Parliament, of which 6 Vice Presidents. Given the fact that prior to the Maastricht Treaty (1993), the President of the Commission had no involvement in appointing the Commissioners, it can be argued that Delors did not build his Commission for the purpose of being political, as can be seen from the team's design from above. In the case of Delors, it is important to mention the reform of the Spokesman Service, by establishing a single chief spokesperson (Hugo Paemen) under his direct supervision, to strengthen his control over public relations. In this regard, Delors urged his new team not to assign the position of spokesman to any member of their offices, having control over public relations and being able to speak on behalf of the entire Commission (Endo, 1999, p. 49).

Secondly, Delors mobilized its resources from double membership in the European Council, recognizing that the full participation in the European Council gives him authority over its colleagues, being more than primus inter pares and thus his policies are difficult to challenge by the other Commissioners. Moreover, since 1985, Delors has become the one presenting important issues of the European Community within the European Council, and as a result, the position of President of the Commission has been raised close to the level of a government leader (Endo, 1999, p. 58).

Thirdly, Delors has created coalitions and networks at the organization level, among the most important being the alliance with the Paris-Bonn Axis and the networks developed by his chief of staff, Pascal Lamy and by the Secretary General, Emile Noël. As for the relationship with Francois Mitterrand and Helmut Kohl, this proved to be advantageous because Delors had their support at the time of taking over as President. This was due in large part to the fact that both the French President and the German Chancellor shared Delors' vision of the single market and the monetary union (Kassim et.al., 2019a, p. 8). Moreover, policies such as the Social Charter or the Media program would not have been possible if Delors had not acted in the sense of influencing Mitterrand for support. In addition, Helmut Kohl proposed Delors as President of the Commission, and their relationship was strengthened the most when Delors supported the unification of Germany, being the first 
European leader to act in this manner (Endo 1999, p. 63). On the other hand, regarding Delors' networks, they play an important role in facilitating the realization of policies, political objectives and in influencing the agenda, being formed on the basis of personal relationships or political ideologies. In this regard, it is worth mentioning the ad hoc networks created in 1984, within the 'Institutional Group', having as main members Noël, Ehlermann, Perissich and Lamoureux, was an important factor in the process of drafting the Single European Act (Endo, 1999, p. 54). In the same vein, the network led by Lamy transformed Delors' presidential cabinet into "the executor of presidential will inside the Commission", thereby monopolizing access to the President. In this regard, Lamy made sure that the proposals of the other commissioners, who did not follow the same direction with Delors, were rejected from the agenda (under the pretext that the agenda is pre-loaded), Lamy making use of Article 4 of the Rules of Procedure, which specifies that the new topics must be notified 10 days before being introduced on the agenda. Also, the most important members of Lamy's network in France were the French Minister of Finance and the École Nationale d'Administration graduates, and in Germany, Joachim Bitterlich (Kohl's adviser on foreign affairs), who represented a strong link between Delors and Kohl (Endo, 1999, pp. 47-48).

Therefore, Delors exercised his political leadership through ad hoc networks, Franco-German tandem relations and by exploiting the resources from double membership in the European Council, factors that allowed him to influence and shape the agenda and attract supporters to follow his desired direction towards the Single European Market and later the European Union.

\section{Jean Claude Juncker}

Juncker has exercised his political leadership by building a political Commission, by reforming the Commission to centralize the power and strengthen the office of the President, but also by consolidating the relationship with the European Parliament.

Regarding the political design of the Juncker Commission, the distribution of resources underwent a series of changes and transformations. These transformations, as were mentioned at the beginning, originate in the Spitzenkandidaten procedure, whereby Juncker states that the European Parliament chose, in the true sense of the word, for the first time: You are the first Parliament to truly elect, in all senses of the word, the President of the Commission. You will elect him in a new spirit. In the aftermath of the elections, you insisted that the results, produced by universal suffrage, had to be taken into account. (Juncker, 2014b, p. 1). In other words, this new interpretation of the Lisbon Treaty gave Juncker the authority and legitimacy that underpinned its reforms on the organization of the Commission. 
First of all, even though the procedure does not allow for the President to choose his team of Commissioners, Juncker went against the procedure to influence the granting of specific portfolios to certain Commissioners, making use of his authority, electoral mandate and prestige to select his team (Kassim \& Laffan, 2019b, p. 52). Thus Juncker's political Commission needed a majority of members to have a political background because a political commission has to be created of experienced politicians, the Commission being political, not technocratic, as he argued in his September 10 speech: We will be political, and not technocratic (Juncker, 2014d, p. 3) and July 15th: The Commission is not a technical committee made up of civil servants who implement the instructions of another institution. The Commission is political (Juncker, 2014b, p. 1). Otherwise speaking, the new Commission structure includes: 9 former Prime Ministers or Deputy Prime Ministers, 19 former Ministers, 7 returning Commissioners and 8 former Members of the European Parliament; 11 of these have a very solid economic and finance background, whilst 8 have extensive foreign relations experience (Juncker, 2014d, p. 1). Secondly, Juncker (2014a, p. 30) changed the way the Commissioners were operating, focusing on cooperation, collaboration and teamwork, forming 7 teams, led by the 7 Vice Presidents, arguing his choice by saying that: you can either have 28 Commissioners, each working in their own little corner, ensconced in splendid isolation, each looking after their own little fief, which is what would happen once the Commission's tasks had been sliced and diced; or you can have Commissioners spreading their wings under the friendly aegis of Vice-Presidents who will coordinate their work. In this regard, Juncker (2014a, p. 29) named the former prime ministers as Vice Presidents, because he considers that they acted as coordinators in their former political careers. Juncker introduced a system of Vice-Presidents, to strengthen coordination between commissioners, to centralize decision-making in the Commission and to make explicit political decisions (Tömmel, 2018, p. 10). Additionally, his Commission is the first one created on two levels, namely the first level of seniors (Vice-Presidents), who supervise the other Commissioners' work. Thus, the Vice-Presidents play the role of: [...] planners, coordinators, drivers, mobilisers, organisers of ideas and initiatives (Juncker, 2014a, p. 30). Furthermore, Juncker has appointed Frans Timmermans as the First Vice President, who becomes his main source of help and has the power to decide whether the initiatives will be discussed by the College and added to the agenda: Another important novelty is the creation of a First Vice-President. Frans Timmermans will be my right-hand (Juncker, 2014d, p. 3). Third, Juncker added new ways of collaborative working for the Commission, highlighting the role and responsibilities of the First Vice President, as well as the Vice Presidents and working teams, the General Secretariat and the Presidential Cabinet in support of the former (European Commission, 2014). 
In this regard, Juncker extended the powers of the First Vice President so that he could remove proposals that did not fit his priorities and consequently 80 out of 450 proposals were removed. Moreover, the spokesmen of the individual commissioners were eliminated to avoid repeating the situation during the Barroso Commission, when they represented the interests of the commissioners more than those of the European Commission (Bürgin, 2017, p. 7).

As for the inter-institutional relations, the most relevant ones are those with the European Parliament, as the Juncker Commission has strengthened and extended these relations. Some of the factors that underpinned the relationship between the Commission and Parliament are: the European Parliament was the main promoter of the Spitzenkandidaten procedure, and the EPP, S\&D and ALDE leaders promised to support Juncker; Martin Schulz ( $S \& D$ candidate and Juncker's friend) became President of the European Parliament; EPP and S\&D concluded a power shifting agreement and formed a coalition, which supported Juncker and his program, by imposing a majority of work on Members of the European Parliament; relations were strengthened by the meetings between Juncker, Timmermans, Schulz, Manfred Weber (EPP leader) and Gianni Pitella (S\&D manager); in Parliament and in trialogues, the Commission was more represented by Commissioners, not officials (Kassim \& Laffan, 2019b, p. 54-55). On the other hand, relations with the European Council were not as cordial as some of the government leaders were skeptical of the Spitzenkandidaten process (they believed that the parliamentary Commission would undermine the authority, legitimacy and status of the supreme institution of the European Council), and in this context, the European Council adopted the Strategic Agenda (June 2014), prior to the appointment of Juncker Commission. However, Juncker and Tusk cooperated in several aspects concerning the European Union, such as: negotiations with Turkey over the refugee crisis, the Ukraine and Greek crisis, Brexit, but the relationship became tense with the management of the refugee crisis. Here, Juncker failed to convince Tusk on the importance and necessity of a quota system for taking over refugees, applied by each Member State (Kassim \& Laffan, 2019b, p. 54).

All these changes in the structure of the Commission and the strong link with the European Parliament represented the basis for the creation of a political Commission and the strengthening of the political leadership of the President of the Commission. However, Juncker failed to fully mobilize resources from the European Council, as relations were visibly strained when involved in the refugee crisis. 


\section{Ursula von der Leyen}

Following, it is important to consider the extent to which Ursula von der Leyen moved closer to Delors or Juncker's leadership model. However, it is worth mentioning that Ursula von der Leyen is still in the first year of her term as President of the Commission, which is why the analysis of her leadership could not be accurate. Therefore, the article will analyze the leadership she proposed in the first months of her term and look at the extent to which she exercised political leadership in the manner in which Juncker did or supranational leadership, based on networks and coalitions as Delors did.

First of all, regarding the political design of Ursula von der Leyen's team, it is important to note that she did not have as much influence as Juncker in the formation of the College of Commissioners. However, the new team has a solid political background, even if it does not rise to the level of Juncker's team, comprising: 2 former Prime Ministers and 1 former Deputy Prime Ministers, 17 former Ministers, 8 returning Commissioners and 9 former Members of the European Parliament, and for the first time since 1995 the European Commission is not chaired by a former head of government. Moreover, Timmermans remained in the position of First Vice-President. Von der Leyen reformed de structure of the Commission as can be seen in the following: firstly, the number of Vice-Presidents was extended to eight; secondly, the eight Vice-Presidents are divided into 3 Executive VicePresidents and 5 Vice-Presidents; thirdly, the three executive vice presidents have a dual role, dealing with a specific portfolio and being responsible for one of the core topics of the political agenda; von der Leyen introduced a new working method namely the Commissioners' Groups, headed by an executive vice-president or vice-president, responsible for delivering coherent policies for the six priorities of the President (European Commission, 2019, pp. 7-8), although these groups are very similar to the cluster structure introduced by Juncker. Another novelty of von der Leyen's (2019c, p. 7) Commission is the creation of a 'geopolitical Commission', as opposed to Juncker's 'political Commission'. Thus, the Commission agenda will be to reinforce the European Union's role in shaping the global order.

Secondly, with regard to the mobilization of resources from the other institutions, von der Leyen's initiative to improve relations with the European Parliament is relevant. In this regard, von der Leyen proposed a series of actions to strengthen the European Parliament's partnership, as follows: support for a right of initiative of the European Parliament (this pledge goes beyond the treaty, in which the Commission has the exclusive right of initiative); the Commissioners will work with the European Parliament and inform it at all stages of legislative design and negotiations; the presence of Commissioners in trialogues discussions between Parliament and the Council; prioritizing a permanent dialogue between the Commission and Parliament; 
full co-decision for the European Parliament; the Commission will broker the discussions between the Parliament and the European Council; improvement of the lead candidate system, specifically of the Spitzenkandidaten process, by making it more visible through addressing the issue of transnational lists which the Parliament rejected in 2018 (Von der Leyen, 2019a, p. 20; Euronews, 2018). However, the process of electing the President of the Commission demonstrated that von der Leyen would not have the same relationship with the Parliament that Juncker had, who contributed to the parliamentary process and was an important ally of the Parliament. Thus, given that she is not a Spitzenkandidat, her appointment encounters several opponents, including from the EPP, who considered this choice to be illegitimate, even if none of the lead candidates (Spitzenkandidaten: Manfred Weber-EPP, Frans Timmermans-PES, Margrethe Vestager-ALDE) would have obtained a majority in the European Parliament. That being said, von der Leyen will face several difficulties in trying to improve relations with a fragmented Parliament, which, although it does not have a stable majority, wants to have a role in the legislative initiative, an important fact that she pledged to do.

Thirdly, it is worth mentioning that von der Leyen was supported by the Franco-German tandem in the appointment process as President of the Commission, with Macron nominating her for this position and thus, ending the institutional deadlock. Von der Leyen also strengthened the alliance with the French President by supporting some of Macron's favourite ideas, such as: negotiations for a minimum wage across states in the EU; support for a tax on revenues generated by digital companies; support for a carbon border tariff; support for the current tax on trade; the creation of a European investment bank dedicated to combating climate change; support for a transnational list for future European elections. However, there were a number of tensions between the two over von der Leyen's declaration of enlarging the European Union in the Western Balkans, which Macron vehemently opposed, and due to support for NATO, an organization criticized by Macron in 2019. On the other hand, the alliance with Germany is found primarily on account that Ursula von der Leyen worked as Minister of Defence in Germany, being the longest-serving member of Merkel's Cabinets. In other words, this FrancoGerman tandem coalition is an important resource for Ursula von der Leyen's success in shaping and influencing the European agenda, especially because in 2020 and 2022 she will be able to mobilize Council resources due to the Germany and France chairing.

Therefore, following the approach taken to identify the leadership model proposed by Ursula von der Leyen, the article argues that her leadership is closest to the leadership proposed by Delors for the following reasons: first, they both set the European agenda from zero-ground, introducing a new 
vision, acting as inventors and shaping thinking; second, they have both strengthened their alliance with the Franco-German tandem, which is von der Leyen's most important external resource for influencing the agenda; thirdly, their appointment was made by the European Council, not by Parliament through Spitzenkandidaten. However, the similarities between Ursula von der Leyen's leadership and Juncker's leadership cannot be ignored. In that regard, it is worth mentioning that Leyen took over from Juncker the way in which the Commission was organized by teams or groups of Commissioners. Moreover, both von der Leyen and Juncker sought to attract the support of the European Parliament, Juncker succeeding in this through the Spitzenkandidaten, and von der Leyen in promising legislative initiative for Parliament. Also, regarding the political nature of the Commissioners, the article argues that Leyen's team is closer to Juncker's than Delors', although its power to influence the appointment of the College was limited, not as in the case of Juncker, who greatly influenced the formation of his team. For that reason, so far, von der Leyen's leadership is closer to a style of supranational political leadership than to that proposed by Juncker, which has somewhat changed the balance of power in the European Union in favour of Parliament. In support of this statement is the following passage from Ursula von der Leyen's (2019c, p. 7) speech: My Commission will not be afraid to speak the language of confidence and assertiveness. But we will do it our way, the European way, where it can be seen clearly that the relationship with the European Parliament will not be the same as it was for Juncker's Commission when he stated that: We, Parliament and Commission, will act in the general interest, and I want us to do it together (Juncker, 2014b, p. 1).

Table 2. The political leadership of the European Commission according to the three variables

\begin{tabular}{|c|l|l|l|}
\hline \multirow{1}{*}{ Delors } & \multicolumn{1}{|c|}{$\begin{array}{c}\text { Political design of the } \\
\text { Commission }\end{array}$} & $\begin{array}{c}\text { Mobilization of } \\
\text { resources from } \\
\text { other European } \\
\text { institutions }\end{array}$ & $\begin{array}{c}\text { Coalitions and ad } \\
\text { hoc networks }\end{array}$ \\
& $\begin{array}{l}-2 \text { former Deputy Prime } \\
\text { Ministers, 9 former Ministers, } \\
\text { 4 returning Commissioners } \\
\text { and 3 former Members of the } \\
\begin{array}{l}\text { European Parliament, of } \\
\text { which 6 Vice Presidents } \\
\text {-reform of the Spokesperson } \\
\text { Service }\end{array}\end{array}$ & -European Council & $\begin{array}{l}\text { - the alliance with } \\
\text { the Paris-Bonn Axis } \\
\text {-the networks } \\
\text { developed by the } \\
\text { head of his cabinet, } \\
\text { Pascal Lamy and by } \\
\text { the general secretary, } \\
\text { Emile Noël. }\end{array}$ \\
\hline Juncker & $\begin{array}{l}-9 \text { former Prime Ministers or } \\
\text { Deputy Prime Ministers, 19 } \\
\text { former Ministers, 7 returning } \\
\text { Commissioners and 8 former } \\
\text { Members of the European } \\
\text { Parliament; }\end{array}$ & Parliament & $\begin{array}{l}\text {-the alliance created } \\
\text { with S\&D and } \\
\text { ALDE }\end{array}$ \\
\hline
\end{tabular}




\begin{tabular}{|c|c|c|c|}
\hline & $\begin{array}{l}-7 \text { teams, led by the } 7 \text { vice } \\
\text { presidents } \\
\text { - the spokespersons of the } \\
\text { individual commissioners } \\
\text { were eliminated }\end{array}$ & & \\
\hline $\begin{array}{l}\text { Von der } \\
\text { Leyen }\end{array}$ & $\begin{array}{l}-2 \text { former Prime Ministers and } \\
1 \text { former Deputy Prime } \\
\text { Ministers, } 17 \text { former } \\
\text { Ministers, } 8 \text { returning } \\
\text { Commissioners and } 9 \text { former } \\
\text { Members of the European } \\
\text { Parliament } \\
\text {-the number of vice-presidents } \\
\text { has been extended to eight ( } 3 \\
\text { executive vice-presidents and } \\
5 \text { vice-presidents) } \\
\text {-Groups of Commissioners, } \\
\text { headed by an Executive Vice } \\
\text { President or Vice President } \\
\text { (similar to Juncker's model) }\end{array}$ & $\begin{array}{l}\text {-European } \\
\text { Parliament }\end{array}$ & $\begin{array}{l}\text {-the relationship with } \\
\text { the Franco-German } \\
\text { tandem. }\end{array}$ \\
\hline
\end{tabular}

\section{Conclusion}

Given the fact that no actor at the European Union level has exclusive leadership and that the President of the Commission has limited decision-making powers, the most relevant political leadership role of the Commission is through the agenda-setting and through shaping and influencing the decision-making process, in order to advance in the desired direction. The agenda-setting is relevant in the current context, along with the new President of the Commission, Ursula von der Leyen, who has outlined the agenda to solve unresolved or partially solved problems by the previous Commission and introduced a novelty on the European agenda through the Green Deal, and thus bringing a new issue on the European agenda, as in the case of Delors, who stood out for one of the most important moments in setting the agenda, namely Single European Market (1985). Regarding the Juncker Commission, on the other hand, it is difficult to identify agenda-setting from zero-ground, rather a continuation of Barroso's agenda, but the novelty consists in the approach to the Commission, as a political one, not a technocratic one. For this reason, this research has compared three Commission Chairs, namely Jacques Delors, Jean-Claude Juncker and Ursula von der Leyen, to identify the leadership model adopted when setting the agenda and how they have exercised political leadership in order to influence the decision-making process and to shape the agenda.

Thus, regarding the agenda-setting leadership, applying the theoretical framework identified by Oran Young (structural, entrepreneurial and intellectual leadership) on the President's speeches (candidacy and inaugural), 
a series of conclusions were reached. First of all, Delors is an entrepreneurial and intellectual leader, largely for his efforts in shaping the European agenda to overcome impediments and achieve joint gains, but most importantly for introducing the idea of the European Single Market and the European Union on the agenda. Secondly, Juncker is an entrepreneurial and structural leader, owing to the brokerage actions regarding the refugee crisis, renewable energy, unemployment, the single digital market and the social-economic market, due to his new vision on a political Commission and his efforts to attract the support of the European Parliament as a result of the Spitzenkandidaten process. Third, Ursula von der Leyen is an entrepreneurial and intellectual leader, in view of the fact that she has shaped and set the agenda for climate issues, stressing the importance of Europe becoming the first climate-neutral continent because she has provided solutions to the inherited issues from the Juncker Commission (migration, Brexit, unemployment), but also for the way she shaped thinking by introducing a new vision, the Green Deal. Thus, the article concludes that one of the most important roles of the President of the Commission can be seen in setting the European agenda, which depends largely on the level of ambition and mobilization of resources, and in this regard, the article emphasizes on the importance of the three leadership styles and the need of the existence of more than one. In other words, the three Commission Presidents largely addressed an entrepreneurial leadership style, which is essential in inter-institutional negotiations, intellectual by introducing innovative visions and structurally by attracting institutions to support their position.

On the other hand, regarding the political leadership, the three variables, namely the political nature of the members of the Commission, the mobilization of resources from the other European institutions and the creation of networks or coalitions were taken into account. First of all, Delors exercised his political leadership the most through ad hoc networks and the relationship with the Franco-German tandem. Secondly, Juncker, as a more special case due to his appointment by the Parliament not by the European Council, exercised his most visible political leadership by influencing the political composition of the Commission, mobilizing resources from the European Parliament and building a coalition with EPP, S\&D and ALDE leaders. Lastly, Ursula von der Leyen acted politically through her relationship with the Franco-German tandem as Delors and by trying to gain the support of the European Parliament as Juncker did, but as in the case of Delors, it had no influence in the formation of a political Commission team.

Therefore, the research has concluded that von der Leyen's leadership model is more closely to Delors's model, although a few similarities can be seen with Juncker's leadership, with the intention to strengthen the relationship with the European Parliament and in the way the Commission was 
organized in several clusters. Even though, given that von der Leyen is only in the first year in office, these results may change in the coming years.

\section{Acknowledgement}

"The author wishes to acknowledge the financial help received from Babes-Bolyai University through research project number 35546, which funded the academic research period. I thank the advisory committee of my Department and the reviewers appointed by the ESJ for their useful comments."

\section{References:}

1. Blondel, J. (1987). Political Leadership Towards a General Analysis. London: SAGE Publications.

2. Borrás, S. (2007). The European Commission as Network Broker. European Integration Online Papers, 11(1).

3. Bürgin, A. (2017). Intra-and Inter-Institutional Leadership of the European Commission President: An Assessment of Juncker's Organizational Reforms. Journal of Common Market Studies, 56 (4): 837-853. DOI: $10.1111 /$ jcms. 12648.

4. Darmé, C. (2019). Pros and Cons of Proactive Political Leadership: A Review of the Legacy of the "Last Chance" Commission. Istituto Affari Internazionali Papers. DOI: 978-88-9368-110-0.

5. Delors, J. (1985). The thrust of Commission policy. Statement by Jacques Delors, President of the Commission, to the European Parliament and extracts from his reply to the ensuring debate. Bulletin of the European Communitites Supplement 1/85, Strasbourg, 14-15 January 1985.

6. Endo, K. (1999). The Presidency of the European Commission under Jacques Delors. London: Palgrave Maccmilan Press.

7. Euronews (2018, February 7). EU parliament rejects transnational lists. Retrieved on April 6, 2020 from https://www.euronews.com/2018/02/07/eu-parliament-rejectstransnational-lists.

8. European Commission (2014, November 11). Communication from the President to the Commission. The Working Methods of the European Commission 2014-2019, C(2014) 9004, Brussels.

9. European Commission (2019, December 1). Communication from the President of the Commission. The Working Methods of the European Commission, $\mathrm{P}(2019) 2$, Brussels.

10. European Union (2008). Consolidated Version of the Treaty on European Union and the Treaty on the Functioning of the European Union. Official Journal of the European Union, C 115/01, 9 May 2008. 
11. Gatti, M., \& Manzini, P. (2012). External Representation of the European Union in the conclusion of International Agreements. Common Market Law Review, 49 (5), 1703-1734.

12. Hanck, P. L. S. (2018). A purposeful opportunist? The Juncker Commission and EMU reform. Bruges Political Research Papers. https://www.coleurope.eu/system/files_force/researchpaper/wp72_sa njurjo.pdf?download $=1$.

13. Hodson, D. (2013). The Little Engine that Wouldn't: Supranational Entrepreneurship and the Barroso Commission. Journal of European Integration, 35 (3), 301-314. DOI: 10.1080/07036337.2013.774779

14. Hodson, D. (2016). Jacques Delors: Vision, Revisionism, and the Design of EMU. In Dyson, K., \& Maes, I. (Eds.), Architects of the Euro: Intellectuals in the Making of European Monetary Union (pp. 212-232). Oxford: Oxford University Press.

15. Juncker, J. C. (2014a, July 15). A new start for Europe. Opening statement in the European Parliament. My Agenda for Jobs, Growth, Fairness and Democratic Change, Political Guidelines for the next European Commission.

16. Juncker, J. C. (2014b, July 15). A new start for Europe. Opening statement in the European Parliament plenary session, Strasbourg, Speech/14/567.

17. Juncker, J. C. (2014c, October 22). Setting Europe in Motion: President-elect Juncker's Main Messages from his speech before the European Parliament. Statement in the European Parliament plenary session ahead of the vote on the College, Strasbourg, Speech/14/705.

18. Juncker, J. C. (2014d, September 10). The Juncker Commission: The Right Team to Deliver Change. Press Conference, Brussels, Speech/14/585.

19. Kassim, H. (2013). A New Model Presidency: José Manuel Barroso’s Leadership of the European Commission. Berlin Social Science Research Center SP IV 2013-502. Retrieved on March 3, 2020 from https://www.econstor.eu/handle/10419/103427.

20. Kassim, H., \& Dimitrakopoulos, D.G. (2006). Leader or Bystander? The European Commission and EU Treaty Reform. In Mazzucelli, C., \& Beach, D. (Eds.), Leadership in the Big Bangs of European Integration (pp. 94-114). London: Palgrave Maccmilan Press.

21. Kassim, H., \& Laffan, B. (2019b). The Juncker Presidency: The 'Political Commission' in Practice. Journal of Common Market Studies, 57 (1), 49-61. DOI: 10.1111/jcms.12941.

22. Kassim, H., Connolly, S., Laffan, B., \& Bocquillon, P. (2019a). The Juncker Commission: A new model of presidentialism?. In 2019 EUSA International Biennial Conference, Denver, Colorado, 9-11 May 2019. 
23. Kleine, M. (2013). Informal governance in the European Union: How governments make international organizations work. Ithaca: Cornell University Press.

24. Maythorne, L., \& Peterson, J. (2010). New Model Leadership in a New European Union. Edinburgh Europa Paper Series. DOI: http://dx.doi.org/10.2139/ssrn.1690989.

25. Mazzucelli, C., \& Beach, D. (2006). Introduction. In Mazzucelli, C., \& Beach, D. (Eds.), Leadership in the Big Bangs of European Integration (pp. 1-21). London: Palgrave Maccmilan Press.

26. Müller, H. (2016). Between Potential, Performance and Prospect: Revisiting the Political Leadership of the EU Commission President. Politics and Governance, 4 (2), 68-79. DOI: 10.17645/pag.v4i2.581.

27. Müller, H. (2017). Setting Europe's agenda: The Commission presidents and political leadership. Journal of European Integration, 39 (2), 129-142. DOI: 10.1080/07036337.2016.1277712.

28. Müller, H. (2019). Political Leadership and the European Commission Presidency. New York: Oxford University Press.

29. Nugent, N. (1995). The leadership capacity of the European Commission. Journal of European Public Policy, 2 (4), 603-623. DOI: 10.1080/13501769508407009.

30. Nugent, N., \& Rhinard, M. (2017). The 'Political' Role(s) of the European Commission. In EUSA Fifteenth Biennial Conference, Miami, Florida, 4-6 May 2017.

31. Nugent, N., \& Rhinard, M. (2019). The 'political' roles of the European Commission. Journal of European Integration, 41 (2), 203220. DOI:10.1080/07036337.2019.1572135.

32. Peterson, J. (2016). Juncker's political European Commission and an EU in crisis. Journal of Common Market Studies, 55(2), 349-367. DOI: https://doi.org/10.1111/jcms.12435.

33. Ross, G., \& Jenson, J. (2017). Reconsidering Jacques Delors' leadership of the European union. Journal of European Integration, 39 (2), 113-127. DOI: 10.1080/07036337.2016.1277718.

34. Tallberg, J. (2006). Leadership and Negotiation in the European Union. New York: Cambridge University Press.

35. Tallberg, J. (2010). The Power of the Chair: Formal Leadership in International Cooperation. International Studies Quarterly, 54 (1), 241-265. DOI: 10.1111/j.1468-2478.2009.00585.

36. Tömmel, I. (2013). The Presidents of the European Commission: Transactional or Transforming Leaders?. Journal of Common Market Studies, 51 (4), 789-805. DOI: 10.1111/jcms.12023.

37. Tömmel, I. (2018). Political Leadership in Turbulent Times - the Commission Presidency of Jean-Claude Juncker: Assessing 
Organizational Change and Policy Impact. In Ege, J., Bauer, M.W., \& Becker, S. (Eds.), The European Commission in Turbulent Times: Assessing Organizational Change and Policy Impact (pp. 133-156). Baden-Baden: Nomos.

38. Tömmel, I. (2019). Political leadership in times of crisis: The Commission presidency of Jean-Claude Juncker. West European Politics, 43 (5), 1141-1162. DOI: 10.1080/01402382.2019.1646507.

39. Von der Leyen, U. (2019a). A Union that Strives for More. My Agenda for Europe. Political Guidelines for the next European Commission 2019-2024.

40. Von der Leyen, U. (2019b, July 16). Opening Statement in the European Parliament Plenary Session by Ursula von der Leyen, Candidate for President of the European Commission, Strasbourg, Speech/19/4230.

41. Von der Leyen, U. (2019c, November 27). Speech in the European Parliament Plenary Session. President-elect of the European Commission, Strasbourg.

42. Young, O. R. (1989). The Politics of International Regime Formation: Managing Natural Resources and the Environment. International Organization, 43 (3), 349-375.

43. Young, O. R. (1991). Political leadership and regime formation: On the development of institutions in international society. International Organization, 45 (3), 281-308. DOI: 10.1017/S0020818300033117. 